\title{
Dirty Money: Is there a Wage Premium \\ for Working in a Pollution Intensive Industry?
}

\author{
Matthew A. Cole* \\ Robert J. R. Elliott* \\ Joanne K. Lindley**1
}

* Department of Economics, University of Birmingham, Edgbaston, Birmingham, B15 2T'T, UK.

** Department of Economics, University of Sheffield, 9 Mappin Street, Sheffield, S10 2TN, UK.

Corresponding author: Robert J R Elliott, Department of Economics, University of Birmingham, Edgbaston, Birmingham, B15 2TT, UK. r.j.elliott@bham.ac.uk, Tel: (44) 01214147700.

\footnotetext{
${ }^{1}$ Matthew Cole and Robert Elliott are grateful for funding from the Leverhulme Trust grant F/00094/AG. We would like to thank Steve McIntosh and participants at EAERE Kyoto, The Health and Safety Executive for useful comments. The usual disclaimer applies.
} 


\begin{abstract}
:
Within a compensating wage differential framework we investigate whether there is a wage premium for working in a pollution intensive industry. Our results for the economy as a whole suggest a small wage premium of approximately one quarter of one percent associated with the risk of working in a dirty job. This premium rises to over fifteen percent for those individuals who work in one of the five dirtiest industries. We also find evidence of a fatal risk wage premium, providing estimates of the value of a statistical life of between $£ 12$ million and £19 million (2000 prices).
\end{abstract}

Keywords: Compensating Wage Differentials, Pollution, Value of Statistical Life.

JEL: J28, J31, Q52. 
In recent years environmental concerns have crept up the political agenda. Alongside the recognition of how economic activity affects climate change there is also an increase in the awareness of how industrial emissions of a variety of pollutants can adversely the health of employees. Indeed, the recent Registration, Evaluation and Authorization of Chemicals law (REACH), one of the largest EU laws ever ratified, oversees the registration of around 30,000 chemicals and provides an EU body with the power to ban those chemicals that are deemed a health threat. According to Vineis and Simonato (1991), between 1 and $40 \%$ of lung cancers and 0 to $24 \%$ of bladder cancers are attributable to workplace exposure. Similarly, Landrigan (1992) estimates that in the US between 50,000 and 70,000 cancer deaths in 1990 were caused by work related toxic exposure together with 350,000 new cases of illness. Finally, the World Health Organization (WHO) estimate that 200,000 people die globally, each year, from cancer related to their workplace (WHO 2007).

Given these health concerns, in this paper we ask whether workers are compensated financially for working in a heavily polluting or dirty industry. We define 'dirty' as an industrial environment where an employee is potentially exposed to a high level of pollutants that may, in turn, have a detrimental effect on that individual's health. If there is a positive probability that an individual will suffer a long or short-term illness, or possibly death, from working in a dirty industry then taking such a job can be considered a form of risk-taking behaviour. As such, workers in dirty industries should be fully compensated for the risks. An alternative way of thinking about this is that firms pollute the local environment and hence workers from the locality demand higher wages as compensation irrespective of work exposure levels. Thus it should be possible to calculate the wage premium associated with such employment by using a traditional hedonic wage methodology. 
The theoretical case for efficient wage compensation rests on the following assumptions: workers are fully informed of the risks of working in a dirty job; they have utility functions where the expected likelihood and costs of exposure to harmful emissions and other occupational hazards enter as arguments; if firms possess information on workers' preferences and expectations; if a pollution-free working environment is costly to provide; and labor markets are perfectly competitive. If any of these conditions fail to fully apply then the actual compensation may be less than utility offsetting or nonexistent. Conversely, compensation can be more than utility offsetting if workers overestimate the risk. Therefore, whether pollution exposure will result in a compensating wage differential is essentially an empirical question. ${ }^{2}$

The contribution of this paper is to provide the first estimates of the wage premia associated with pollution risk. We use disaggregated industry-level pollution data and individual-level wages and characteristics. In addition we provide estimates of the value of statistical life (VSL) for the UK and the first estimates employing data from the UK Labour Force Survey (LFS). The main finding of our paper is the existence of a positive and significant wage premium attached to working in a dirty

\footnotetext{
2 A lively debate on the existence of wage compensation continues. See Dorman (1996) for a broader discussion of these assumptions and theoretical reasons for doubting their applicability. Most value of statistical life (VSL) studies centre on one basic premise: that the VSL should roughly correspond to the value that people place on their lives in private decisions. See Viscusi (1993), Dorman and Hagstrom (1998) and Viscusi and Aldy (2003) for a review of the existing literature and Mrozek and Taylor (1999) for the results of an often cited meta-analysis on the determinants of the value of life. Mrozek and Taylor (1999) offer a best practice estimate of VSL of \$2million (1998 prices). Note that their estimates are considerably less than the Environmental Protection Agency (EPA) VSL value of \$6 million (1998 dollars). Burtraw et al. (1998), Hagler-Bailly (1995) and USEPA (1997) all show that the benefits far outweigh the abatement costs even if VSL figures were to be reduced by two thirds. See Viscusi (2007) for an overview of the regulation of health, safety and environmental risks
} 
industry, across a range of pollution exposure measures. This finding is robust to a battery of sensitivity checks. The average weekly wage premium across all industries is found to be between $£^{0.20}$ and $f^{0.80}$ equivalent to between $0.1 \%$ and $0.4 \%$ of weekly wages. For the most pollution intensive industries the weekly wage premium is between $£, 17.40$ and $£ 125.90$, equivalent to between $6.5 \%$ and $30.0 \%$. A secondary result is that we also find evidence of a weekly wage premium compensating for the risk of fatal accidents. Across all industries, this premium is between $£ 1.30$ and $£ 1.50$ per week, equivalent to between $0.54 \%$ and $0.63 \%$ of weekly wages. Finally, our fatal risk results provide estimates of the VSL of between $£, 12 \mathrm{~m}$ and $£ 19 \mathrm{~m}$ in 2000 prices, although we find no significant value of statistical injury. ${ }^{3}$

The remainder of this paper is organised as follows: Section 1 reviews the literature on the impact of pollution on health and also examines the wage-risk literature to identify the difficulties associated with estimating compensating wage differentials; Section 2 outlines our methodology and describes our data; Section 3 presents our results while Section 4 concludes.

\section{Review of the Literature}

Little has been written on the impact of industrial pollution on wages. In this section we discuss the relationship between wages, job risk and pollution. First, we briefly discuss how pollution can affect an individual's health and thus the riskiness of working in a given industry. Second, we consider the

\footnotetext{
${ }^{3}$ UK estimates of VSL have often been notably different to those estimated for the US (see Viscusi and Aldy 2003).
} 
factors that may hinder the estimation of pollution related wage-premia and conclude with a brief discussion of pollution risk within the context of the inter-industry wage differential literature. ${ }^{4}$

Our first consideration is the link between pollution and health. The effects of ozone and Particulate Matter (PM10) on health are those most commonly studied because it is these substances that most frequently exceed air quality guidelines (Cesar et al. 1999). The health risks due to air pollution (specifically ozone and PM10) are quantified by estimating the relationship between the incidence of adverse health effects and air quality. A number of quantitative estimates of exposure-response relations of known health effects from various cities have been pooled together (meta-analysis). The findings are that air pollutants can affect health in a number of ways, including eye irritations, respiratory diseases, cardiovascular effects and premature death. ${ }^{5}$

4 There are a small number of studies that have examined the impact of environmental regulations on employment although they generally find little effect. For the US, studies by Morgenstern et al. (2002) and Berman and Bui (2001) find no evidence to suggest that regulations have adversely affected industrial employment with the former actually finding weak evidence that regulations may result in a small net increase in employment. Cole and Elliott (2007) find a similar result for the UK. However, studies by Henderson (1996), Kahn (1997) and Greenstone (2002), again for the US, indicate that industries located in counties with stringent regulations have experienced job losses, or at the very least, lower employment growth rates, relative to industries in less regulated counties.

5 Ozone pollution stems mainly from emissions of Nox and VOC's with concentration levels depending on the amount and location of emitted pollutants, geographical characteristics, meterorological conditions, and atmospheric chemistry and transport. Ozone formation is complicated and non-linear, for example, under certain conditions an increase in Nox can reduce ozone concentrations. PM10 pollution stems mainly from direct emissions of particles, and from reactions of NOX and SO2 with other substances in the atmosphere. Potential emission sources are building and construction, diesel trucks and buses, forest fires, refuse burning and some manufacturing industries. See Cesar et al. (2001) for details. 
The adverse effects of air pollution are related to the rate at which lung tissue ages and can contribute to chronic lung and cardiovascular disease. Short-term peaks in air pollution (and hence acute exposure) can affect people in weakened states (such as those with pneumonia or asthma) and can lead to premature death. Dockery et al. (1993) and Pope et al. (1995) are two studies that follow a cross-section of individuals across time and measure both the exposure to air pollution and other factors that may lead to premature death. These studies calculate survival functions (the probability that a person survives to each age in a given community) and find that pollution results in the loss of a significant number of life-years.

A final consideration is that although a significant amount of information is available on the effect on health of asbestos, vinyl cloride, coke emissions, benzene, arsenic, cotton dust, acrylonitrile, lead and ethylene oxide, not a great deal is known about whether the many chemicals that workers are exposed to at work are cancer-causing and whether or not threshold effects exist. According to the WHO, the most common types of occupational cancers are lung cancer, mesothelioma and bladder cancer with every tenth lung cancer death being closely associated to risks in the workplace. In a recent WHO press release to mark World Day for Safety and Health at Work they write "Currently, most cancer deaths caused by occupational risk factors occur in the developed world. This is a result of the wide use of different carcinogenic substances such as blue asbestos, 2-napthylamine and benzene 20-30 years ago". A scientific literature is emerging on the long-term effects of chemicals, but as many of the effects may take many years to become apparent, and since it might be combinations of chemicals that result in synergistic effects, considerable difficulties arise in locating carcinogens (Kostiuk 1990). 
In many cases, exposure to workplace pollutants would be obvious to the worker. Some chemicals have distinctive smells (e.g. sulfur) or would result in a loss of local visibility (e.g. particulate matter), while others would be evident because of their impact in causing eye irritation or tightness of breath. However, the presence of some pollutants would be less evident, particularly those that are odourless and cause only longer term health problems. There is only a small literature that discusses an individual's perceived pollution risk and hence the likelihood that an individual would demand a wage premium. There are several primary reasons why "dirty" wage premia may be difficult to identify empirically.

The first reason is a lack of knowledge by employers or employees, and the public, on the impact of pollution on health and disease (or a lack of awareness of the existence of pollution). This in turn may undermine the market's ability to generate compensating wage differentials. Shilling and Brackbill (1979) estimate that only about 5\% of workers were fully informed of the job hazards of their occupations. In a related study, Brown (1987) interviewed workers in dangerous chemical plants and concluded that, although workers were fully aware of the risks that they faced, they employ a psychological defence mechanism of denial by refusing to believe that the probability of death or serious injury is high. This is less of a concern in this paper, as we do not use self-reported risk. However, in contrast, Viscusi and O'Connor (1984) find that US chemical workers are aware of the risks to which they are exposed and received compensating wage differentials comparable to those found for objective risk measures.

A second consideration is that health problems (or indeed nonfatal injuries) may be compensated expost. Hence dirty or risky jobs have to be only partly compensated ex-ante through higher wages due to the presence of worker compensation benefits that may be written into a worker's contract. For 
example, retirement, pensions, training, vacation pay etc. Lott and Manning (2000) and Wiggins and Ringleb (1992) examine this issue from a legal standpoint and show that allowing employees to sue their employer has resulted in firms reorganizing and divesting themselves of hazardous facilities in the hope of gaining protection from potential law suites.

Third, it can be argued that individuals' perceptions of risk are heterogeneous so, for example, ethnic minorities and those from lower socio-economic backgrounds may have different perceptions of risk or at least be less geographically mobile and hence have fewer alternative employment options (Viscusi 2003). Leeth and Ruser (2003) include sex and ethnic dummies to address Viscusi's (1993) point on possible risk preference differences across sex and ethnicity. It is also possible that wage premia will differ with age as older workers, with a shorter discounted expected future, are risking less of their life. In a US study, Leeth and Ruser (2003) find that both workplace fatalities and injuries are higher for men than women and for blacks and Hispanics than for whites and other minorities. Variation in risk preference among groups, perhaps caused by income, family background or social norms may produce differences in risk. ${ }^{6}$ However, once the occupational

\footnotetext{
${ }^{6}$ In a study for the US Viscusi (2003) reveals that blacks do face a higher fatality risk and nonfatal injury-risk but that the differences are not great. He also shows that black employees receive significant premia for nonfatal risks. The problem, however, is that although black employees undertake greater risk than whites, they also receive lower annual pay. Viscusi (2003) states that “...there must be fundamental differences in labor market opportunities for blacks and whites as well as the structure of their offers for risky jobs” pg. 254. For non-fatal injury both men and women earn a wage differential but this figure is three times larger for women. Leeth and Ruser (2003) also show that white women earn the highest wage compensation for non-fatal risk. Black, Hispanic and other minorities also receive higher pay for bearing nonfatal injury risk but the premia were smaller than for white women.
} 
distribution of workers is accounted for they find there is no premium for males but do find that men and women in blue-collar jobs earn a premium that does not exist for white-collar jobs. ${ }^{7}$

The existence of inter-industry wage differentials is a further obstacle to the estimation of an industry level pollution-wage premia. Failing to control for other sources of industry wage premia would bias the results. Broadly speaking, blue-collar workers in mining; construction; manufacturing; and transportation receive relatively high wages while those in wholesale; retail; finance; and services, receive lower wages (Leigh 1995). The inter-industry wage literature has provided many explanations for the persistence of pay differentials. Brown and Medoff (1989) for example demonstrate that, ceteris paribus, larger employers will pay higher wages. Other explanations for inter-industry wage differentials include compensating for the likelihood of sectoral unemployment (Murphy and Topel 1987), regional unemployment (Blanchflower and Oswald 1994), union power or segmented markets (Dickens and Katz 1987) or industry shocks that persist over many years due to labor immobility or

${ }^{7}$ A related issue is the controversy surrounding unobservable worker heterogeneity and VSL estimates. One recognised problem with all wage-risk studies is the issue of endogeneity, as raised by Garen (1988). It is possible that those workers with the greatest earnings capacity are likely to choose safer and less pollution intensive working environments (assuming safety and pollution-free working conditions are normal goods). After attempting to control for endogenity issues, Garen (1988) finds generally larger VSL estimates. However, as Kostiuk (1990) points out, Garen’s (1988) methodology removes unobserved worker heterogeneity as an influence on the estimates. This is fine if the unobserved heterogeneity is the behaviour of workers in the face of risk alone. However, differing risk parameters across workers are a necessary condition for the market to generate compensating wage differentials unless we assume individuals' indifference curves are identical. The Garen technique therefore removes too much. Nevertheless, we utilise the Garen methodology to control for the possible endogenity of our fatal, nonfatal and pollution risk variables. The coefficient on nonfatal risk did not alter significantly and remained insignificant and had little impact on the pollution risk coefficient. We are unable to instrument for possible endogeneity between wages and pollution intensity as no suitable instruments is available. Results when fatal and nonfatal risk are instrumented are available from the authors upon request. 
a larger proportion of experienced or tenured workers in particular industries (Helwege 1992). Finally, numerous studies argue that highly unionised industries have a greater opportunity to influence wage decisions (and working conditions). See Duncan and Stafford (1980) and Viscusi and Aldy (2003) for a review of the trade union effect.

Within the inter-industry wage differential literature there is still considerable debate about the extent to which unobserved individual heterogeneity is responsible for inter-industry wage differentials (see e.g. Blackburn and Neumark 1992 and Gibbons and Katz 1995). Hence, individual level characteristics are often included to control for individual heterogeneity. The individual controls are generally the same as those in the VSL literature. ${ }^{8}$

Wherever possible, we try to overcome the obstacles outlined above. To minimise the possibility of unobserved individual heterogeneity affecting wages we control for a wide range of individual characteristics when estimating wages, as discussed below. Similarly, the inclusion of industry-level dummies allows us to control for inter-industry wage differentials.

Whether or not workers are compensated ex post for the risks that they face and whether or not they are actually aware of these risks is an empirical question that further motivates our study. The fact that we find such premia to exist suggests that workers are at least partially aware of the risks that they are exposed to and, furthermore, they are not fully compensated for them ex post.

\footnotetext{
8 Dickens and Katz (1987) find that roughly a quarter of individual level wage variation is explained by industry level wage premia casting doubt on the ability of unmeasured worker heterogeneity to account for industry wage differentials.
} 


\section{Methodology and Data}

In any econometric analysis of compensating wage differentials it is important to be aware that the raw data tends to show a correlation between risk (however measured) and lower wages (Robinson 1991). Therefore, evidence of wage compensation is dependent on the econometric specification.

In this paper we go to considerable lengths to ensure that we identify the relationship between risk (exposure to pollution and fatal and nonfatal injury) and wages. We use economic theory and previous empirical studies to justify our choice of explanatory variables.

Assume individual $i$ has a choice of employment from a range of different possibilities and that each choice offers different probabilities of job related ill health either through fatal and nonfatal injury or the existence of numerous pollutants known to be detrimental to health. Let $f_{j p} r_{j t}$ and $p_{j t}$ represent the probability of fatal, non-fatal and pollution related risk for a particular job respectively. In order to examine the impact of our risk variables on wage rates we estimate a semi-log wage equation (1):

$\ln w_{i t}=\beta_{0}+\beta_{1} p_{j t}+\beta_{2} f_{j t}+\beta_{3} r_{j t}+\beta^{\prime} X+\varepsilon_{i t}$

where $w_{i t}$ denotes the wage of individual $i$ in year $t, p_{j t}$ represents pollution exposure (defined below) in industry $j, f_{j t}$ and $r_{j t}$ represents fatal and nonfatal risk in industry $j$ in year $t$ respectively and $X$ is a vector of other determinants of wages that includes industry and individual level characteristics. $\varepsilon_{i t}$ is the error term. 
Pollution exposure $p$ is trying to capture the degree of pollution exposure that an individual is subjected to in the workplace. We utilise industry-level emissions of 21 different pollutants which we weight according to toxicity and aggregate into four broad groups. Throughout this paper we employ industry definitions used by the UK Environmental Accounts (EA). The EA categorisation is based on the Standard Industrial Classification 1992 (SIC92). Our 81 industries provide coverage for all sectors of the economy. In all we have six primary industries, 39 secondary and 33 service industries. See Table 4 in the Appendix for a list of industries included in our sample. We believe this provides a comprehensive and representative cross-section of the UK economy. We acknowledge the existence of aggregation issues because of our industry level measures where the ideal measure of pollution exposure would be at the plant level but our choice is as disaggregated as possible given the data constraints. ${ }^{9}$

In order to weight by toxicity we use the Threshold Limit Values (TLVs) reported in the American Conference of Governmental Industrial Hygienists (ACGIH) publication '2004 Threshold Limit Values for Chemical Substances and Physical Agents'. As Brooks and Sethi (1997) clarify, a TLV is the maximum airborne concentration of a substance to which a worker may be repeatedly exposed for an eight-hour workday and 40 hour working week without suffering adverse health effects. Of our 21 pollutants, $\mathrm{CO}_{2}$ has the highest TLV at $9,000 \mathrm{mg} / \mathrm{m}^{3}$ while arsenic has the lowest TLV at 0.01 $\mathrm{mg} / \mathrm{m}^{3}$. Having weighted each pollutant by its TLV we then aggregate the 21 weighted pollutants into four groups, namely: (i) all 21 pollutants; (ii) heavy metals; (iii) traditional local air pollutants; and (iv) other pollutants (all non-heavy metals). See Table 5 in the Appendix for details.

\footnotetext{
9 The UK Environmental Accounts (EA) use a combination of 2, 3 and 4-digit SIC codes. See http://www.statistics.gov.uk/.
} 
We construct a proxy of individual exposure of working in firm $f$ in industry $j$ at time $t$ denoted as $E X P_{f f r}$ We provide three alternative measures of $E X P_{f f t}$ for each of our four pollutant groups where "emissions" are either total pollution, heavy metals, local pollutants or other pollutants. We describe each exposure measure and explain under which assumptions each proxy is an appropriate measure of exposure risk.

Measure 1, which we call 'Pollution', is simply defined as emissions in industry $j$.

$$
\text { EXPOSURE }_{f j t}=\text { EMISSIONS }_{j t}=\text { Pollution }
$$

Pollution would be a reasonable proxy of the pollution exposure from working in firm $f$ at time $t$, if all industries have the same number of firms.

Measure 2, 'Pollution per unit of value added' is defined as total emissions in industry $j$ scaled by gross value added (GVA) in industry $j$.

$\operatorname{EXPOSURE~}_{f j t}=\frac{\text { EMISSIONS }_{j t}}{G V A_{j t}}=$ Pollution per unit of value added

Pollution per unit of value added would be a reasonable proxy of the pollution exposure from working in firm $f$ at time $t$, if all firms in industry $j$ have the same level of GVA.

Measure 3, 'Pollution per firm' is defined as total emissions in industry $j$ scaled by the number of firms in industry $j$. 
$\operatorname{EXPOSURE~}_{\text {fit }}=\frac{\text { EMISSIONS }_{j t}}{\text { No.FIRMS }_{j t}}=$ Pollution per firm

Pollution per firm would be a reasonable proxy of the pollution exposure from working in firm $f$ at time $t$ if all industries have firms of the same size. We are unfortunately unable to ascertain which of our measures forms the most accurate measure of exposure. For that reason, and as part of our sensitivity analysis, all three measures are tested for each of our four pollution groupings. It is easy to think of reasons why industry level emissions, however measured, are not accurate measures of exposure. For example, if pollution is emitted from a high chimney it is possible that local residents would suffer more from the fallout that those employed in the factory. Likewise, plant location or industrial clustering may have a significant affect on exposure levels not captured by our variables. However, if pollution affects the local community wages may still reflect the demands of the local population who work in the polluting factory. ${ }^{10}$

Our individual-level characteristics are obtained from the Quarterly Labour Force Survey (QLFS). We use micro data for male and female manual workers taken from the QLFS for 1995-2003. ${ }^{11}$ The main advantage of the QLFS is that it contains a wealth of information on the employment and

${ }^{10}$ In unreported results we also use a fourth exposure measure, namely pollution per worker. Results were broadly similar to those for the other exposure measures but are omitted for reasons of space. They are available upon request.

11 The QLFS is a rotating panel that follows the same individuals for five consecutive quarters. It currently includes a representative sample of approximately 60,000 households made up of five "waves", each of approximately 12,000 households. A systematic random sample design is used for the survey and it is therefore representative of the whole of Great Britain. All estimates based on the LFS are subject to sampling error. Our sample excludes the self-employed. Care is taken to ensure that individuals are not replicated. 
socio-economic characteristics of individuals. Our fatal and non-fatal data are from the Health and Safety Executive (HSE). This approach to deriving an incidence rate of injury is described in a special feature of the Employment Gazette (December 1992) by Stevens (1992). Our sample size is approximately 53,000 individuals. Our dependent variable is the log of wages and is measured as an individual's weekly wage. Estimates with hourly wages give broadly similar results. ${ }^{12}$

The main results in this paper are derived from a sample of male and female manual workers. Costa and Kahn (2004) consider only male production workers between the age of 18 to 45 (or prime aged males) who they argue are the individuals that are likely to be the most sensitive to risk (Viscusi and Aldy 2003). In our sensitivity analysis we therefore estimate our results for males only and for both production and non-production workers. Results are available upon request. ${ }^{13}$

A final issue is the possibility of selection bias as a result of assigning average industry (or occupation) risk to individual workers (Lipsey 1976). Note that a statistically significant positive coefficient on any pollution variable represents a wage premium captured by the employee for working in a dirty industry. It is therefore an industry wage premium that is shared by all workers in that industry whatever their (unobservable) level of individual risk. For example, shop floor workers in a chemical plant are assumed to have the same risk premium as secretaries working in the offices

\footnotetext{
${ }^{12}$ The difference between weekly pay and hourly pay is that the former includes usual hours of paid overtime.

${ }_{13}$ Bellman (1994) uses occupational risk variables for blue-collar workers for Germany and finds a significant positive effect for non-fatal occupational illness of male employees, controlling for schooling, experience and change of industry. However, for nonfatal injuries at work the coefficient was significant and negative. He concluded that for Germany there was no explicit evidence for the existence of compensating wage differentials, especially for non-fatal risk. In contrast, Grund (2000) finds evidence of compensating wage differentials for increased accidents for blue-collar workers in West Germany.
} 
possibly away from the source of the pollution or injury risk. Many previous studies in this area merge industry or occupation level fatal and non-fatal injury risks to individual workers (with some exceptions such as Duncan and Holmlund (1983) and Viscusi (2004)). The attribution of average measured risk to individuals may be inexact because categorical risk is likely to be mis-measured and imperfectly correlated with individual risk. We attempt to minimise this potential problem by concentrating on manual workers. ${ }^{14}$

Returning to equation (1), alongside pollution exposure, vector $X$ contains a large number of individual-level and industry-level explanatory variables motivated by the inter-industry wage differential literature. To account for the effect of industry and occupational dummies discussed by Dillingham (1985) and Leigh (1995), we include a broad occupation dummy and sector dummies. This allows us to take account of the important inter-industry wage effect. We also include firm size following Brown and Medoff (1989), unemployment rates by region (Blanchflower and Oswald 1994), union power or segmented markets (Dickens and Katz 1987), industry growth and industry size (Helwege 1992) and the capital intensity of an industry. ${ }^{15}$ Because applying industry-averaged data to individuals reduces the number of truly independent variables we cluster our standard errors by our industry classification to adjust the standard errors for unobserved industry attributes (Moulton 1990).

\footnotetext{
14 The majority of studies are US based and merge industry-average risk measures (BLS at 2 or 3-digit) or the NIOSH's National Traumatic Occupational Fatality project which reports fatalities by 1-digit industry. Seven of the eight studies summarised in Droman and Hagstrom (1998) use these data sets.

${ }^{15}$ Import and export variables are not included as our sample has both tradable and non-tradable sectors.
} 
To account for as much unobserved individual heterogeneity as possible we include a range of individual level characteristics. For example, following Leeth and Ruser (2003) we include sex, a foreign born dummy and ethnic dummies as well as the standard human capital controls for an individual level wage equation such as region of residence, qualifications, age, marital status, tenure, and a measure of general health. Whether or not an individual is a homeowner was initially included but dropped due to the standard endogenity concerns. The positive sign and significance was as expected and the results for other variables do not change. We also split ethnicity into 9 groups: White; Black Caribbean; Black African; Black Other; Indian; Pakistani; Bangladeshi; Chinese; and Other ethnic and include 11 UK regions: North; Yorkshire; North West; East Midlands; West Midlands; East-Anglia; South East; South West; Wales; Scotland; and Northern-Ireland. To address the productivity issues of Hwang et al. (1992) and Shogren and Stamland (2002) we include five different levels of qualifications to proxy unobservable productivity or skills namely: a degree; Alevels; O-levels; other qualifications; and no qualifications. Finally to control for other potentially undesirable job attributes we include a dummies for shift-working, evening work and night work.

\section{Results}

Our results stems from estimates of equation (1) for our three alternative exposure measures and four different pollutant groups. In Table 1 we report the OLS coefficients on our pollution, fatal and nonfatal risk variables for each of the twelve individual specifications. Table 1 also reports the 
coefficients on pollution from a base specification where fatal and nonfatal risk are omitted, again for the twelve different specifications. ${ }^{16}$

[Table 1 about here]

In line with the previous VSL literature we find a significant and positive coefficient on fatal risk that is fairly constant across pollutants and pollution risk variables. When we calculate the VSL based on an average wage of $£ 11,460$ and 2000 prices the estimates range between $£_{12}$ million and $£^{19}$ million (US\$17.8 and US\$28.1 at an average year 2000 exchange rate of 1.48). This range is considerably higher than US estimates but is more consistent with previous UK studies. For example, again using 2000 prices, Arabsheibani and Marin (2000) estimate a UK VSL of \$19.9 million, Sandy et al. (2001) estimate a UK VSL range of $\$ 5.7$ million to $\$ 74.1$ million and Siebert and Wei (1994) estimate a UK VSL range of $\$ 9.4$ million to $\$ 11.5$ million. ${ }^{17}$ Our coefficient on non-fatal risk is insignificant and remains so even if we drop fatal risk.

An examination of the coefficient on the exposure risk variable reveals that it is positive in all twelve regressions and significant in six of them. When pollution risk is scaled by value added it is positive and significant in three out of four regressions. Comparing the results with and without the inclusion of fatal and non-fatal risk we can see that the statistical significance of the pollution exposure risk variables is unaffected by the inclusion of fatal and non-fatal risk. However, it can be seen that the magnitude of the pollution coefficient is generally larger in the models that exclude fatal and non-fatal risk, suggesting some correlation between pollution risk and other forms of risk. In

\footnotetext{
${ }^{16}$ Appenidix 3 contains the sample means of all of the variables used in Table 1.

${ }^{17}$ None of these UK studies use our richer LFS dataset.
} 
principle the overlap between pollution risk and fatal and non-fatal injuries should be minimal since the latter measures relate to workplace accidents, the vast majority of which would be unrelated to industrial pollution exposure. In contrast, the pollution risk measures are capturing longer term health risks.

The coefficients and significance of the other explanatory variables are broadly as expected. Full specification results for All Pollutants for pollution per unit of value added, pollution per firm and pollution, respectively are provided in Table 7 in the Appendix. For reasons of space we do not report full results for Heavy Metals, Local Air and Other Pollutants, these are available on request. The default individual is native born; white; male; no qualifications; lives in the South West; works in the agricultural industry, does not work any type of unsociable hours and is a non-manager. The following are broadly negative and significant determinants of wages: female; age squared; health and the majority of our measures of ethnicity. Regional unemployment; physical capital intensity (nonwage value added) and growth in gross value added (industry growth) are generally negative and insignificant. Broadly positive and significant determinants of wages are: union density; GVA; the size of the firm; sectoral unemployment; individual age; qualifications; whether foreign born; whether married; whether working in the manufacturing sector. These results are generally as expected (except perhaps the sectoral unemployment rate) and are similar to the majority of compensating wage differential studies. 


\subsection{Calculating Weekly Wage Premia}

We now seek to calculate weekly wage premia associated with working within the five most pollution intensive industries. In order to do this we firstly rank industries in terms of the three exposure measures (for 'all pollutants') and then add the three rankings. Industries are then ranked again in terms of this sum of rankings and from this we identify the 5 most pollution intensive industries. We create dummy variables for these 5 industries and interact them with our pollution variables and include them in equation (1) alongside our main pollution variables. This allows us to identify whether the impact of pollution on wages is higher in these industries than across industries overall. In turn, this allows us to estimate weekly wage premia for these industries. Table 2 presents the estimated coefficients on the interactions between dummy variables for the 5 dirtiest industries and pollution variables. We also report the coefficients on fatal and non-fatal risk (all other coefficients are omitted for reasons of space).

[Table 2 about here]

Table 3 presents actual industry level wage premia for our five dirtiest industries in monetary terms. We present the actual weekly wage premium in pounds sterling and the percentage of the weekly wage that this constitutes.

[Table 3 about here] 
For pollution, if we exclude the Extraction of Oil and Gas (SIC11+12) and SIC (23), that may have large premia for reasons not controlled for in this paper such as unsociable working conditions, the largest wage premia in percentage terms are around 15\% for Other Organic Basic Chemicals (SIC2414) and Other Inorganic chemicals (SIC2413). In absolute terms this translates into an increase in the weekly wage of around $f, 50$. The remarkably small differences across pollution exposure measures in terms of magnitude or ranking of industries gives us confidence that our three proxies are capturing an element of an individual's pollution exposure albeit indirectly.

Table 3 also provides fatal risk premia, allowing a comparison with pollution premia. Across all 81 industries, the average weekly fatal risk premium ranges from $£ 1.30$ to $£ 1.50$ (0.54\% to $0.63 \%)$. The equivalent figures for pollution premia are $f^{0.20}$ to $f^{0.80}(0.1 \%$ to $0.4 \%)$ across all 81 industries. Converting to annual figures and multiplying by the total manufacturing labour force of 3,264,343 (2003), provides total annual fatal risk compensation of between $£ 220.7$ million and $£ 254.6$ million and total annual pollution risk compensation of between $£^{33.9}$ million and $£^{135.8}$ million.

\section{Conclusions}

The compensating wage literature is well established and numerous papers investigate both the causes of inter-industry wage differentials and how these differentials, applied to fatal and nonfatal risk, can be used to estimate the VSL. In this paper we investigate, for the first time, whether an industry's level of pollution emissions weighted by toxicity is sufficient to generate a wage premium for working in a dirty industry. 
Although theoretically and intuitively plausible, we discuss numerous empirical and theoretical arguments as to why exposure to pollution may not be translated into greater wage demands and hence a wage premium. After taking care to fully specify our econometric model in light of these arguments our results provide wage premia estimates of one half of one percent across all sectors of the economy although this rose to an average of approximately $15 \%$ for workers in one of the five dirtiest industries. Our estimates of the VSL for the UK range between $f_{12}$ and $f_{19} \mathrm{~m}$ in 2000 prices. These are consistent with previous UK studies although they are more than double the accepted US estimates. We believe one reason is because the risk of a fatal injury at work is significantly lower in the UK than other countries that have been subject to VSL studies.

The policy implications are clear. Although a reduction in exposure need not have an impact on productivity and efficiency per se, an increase in pollution abatement by UK companies should lead to an improvement in working conditions and thus lower levels of sickness absence, reductions in compensation payments etc. Along these lines it would be interesting to extend the analysis in this paper to investigate the relationship between industry emissions and the incidence of ill-health or sickness absence. Following the initial work of this paper it might also be useful in future work to determine which type of emissions correspond better to actual exposure and estimate with those emissions only. This will require a much greater understanding of the health literature. 


\section{References}

Arabsheibani, G.R. and Marin, A. (2000), Stability of Estimates of the Compensation for Danger, Journal of Risk and Uncertainty, Vol. 20, 3, pp. 247-269.

Bellman, L. (1994), Entohnung als Risikokompensation. Mitteilungen aus der Arbeitmarkt- und Berufsforschung Vol. 4, pp. 351-358.

Berman, E. and Bui, L.T.M. (2001), Environmental Regulation and Labor Demand: Evidence from the South Coast Air Basin. Journal of Public Economics, 79, pp. 265-95.

Blackburn, M. and Neumark, D. (1992), Unobserved Ability, Efficiency Wages, and Inter-industry Wage Differentials, Quarterly Journal of Economics, Vol. 107 (4), pp. 1421-36.

Blanchflower, D.G. and Oswald, A.J. (1994), The Wage Curve, Cambridge,

Brown, M.S. (1987), Communicating Information about Workplace Hazards: Effects on Worker Attitudes toward Risks, in The Social and Cultural Construction of Risk, ed. B. B. Johnson and V. T. Corello. Boston, Mass.: D. Reidel Publishing.

Brown, C. and Medoff, J. (1989), The Employer Size-Wage Effect, Journal of Political Economy, Vol. 97, 5, pp. 1027-59.

Burtraw, D. Krupnick, A. Austin, D. Mansur, E. and Farrell, D. (1998), The Costs and Benefits of Reducing Air Pollutants Related to Acid Rain, Contemporary Economic Policy, Vol. 16, pp. 379-400.

Cesar, H., Borja-Aburto, V.H., Cicero-Fernandez, P., Dorland, K., Munoz Cruz, R., Brander, L., et al. (2001), Improving Air Quality in Metropolitan Mexico City: An Economic Valuation, policy research paper 2785: Washington, D.C: World Bank.

Cole, M. A. And Elliott, R.J.R. (2007), Do Environmental Regulations Cost Jobs? An Industry-Level Analysis of the UK, The B.E. Journal of Economic Analysis \& Policy, Vol. 7.1. 
Costa, D.L. and Kahn, M.E. (2004), Changes in the Value of Life, 1940-1980, Journal of Risk and Uncertainty, Vol. 29, 2, pp. 159-180.

Dickens, W.T. and Katz, L. (1987), Inter-Industry Wage Differentials and Industry Characteristics, in Unemployment and the Structure of Labor Markets, (K. Lang and J. Leonard, Eds.), Basil Blackwell, London.

Dillingham, A.E. (1985), The Influence of Risk Variable Definition on Value of Statistical Life Estimates, Economic Inquiry, Vol. 24, 2, pp. 277-94.

Dockery, D, and others, (1993), An Association Between Air Pollution and Mortality in Six U.S. Cities, New England Journal of Medicine, Vol. 329, 24, pp. 1753-59.

Dorman, P. (1996), Markets and Mortality: Economics, Dangerous Work, and the Value of Human Life, Cambridge University Press.

Dorman, P. and Hagstrom, P. (1998), Wage Compensation for Dangerous Work Revisited, Industrial \& Labor Relations Review, Vol. 52, 1, pp.116-135.

Duncan, G.J. and Stafford, F.P. (1980), Do Union Members Receive Compensating Differentials, American Economic Review, Vol. 70, pp. 355-371.

Duncan, G.J. and Holmlund, (1983), Was Adam Smith Right After All? Another Test of the Theory of Compensating Differentials, Journal of Labor Economics, Vol. 1, pp. 367-379.

Garen, J. (1988), Compensating Wage Differentials and the Endogeneity of Job Riskiness, Review of Economics and Statistics, pp. 9-16.

Gibbons, R. and Katz, L.F. (1995), Does Unmeasured Ability Explain Inter-Industry Wage Differentials? Review of Economic Studies, Vol. 59 (3), pp. 515-35.

Greenstone, M. (2002), The Impact of Environmental Regulations on Industrial Activity: Evidence from 1970 and 1977 Clean Air Act Amendments and the Census of Manufacturers. Journal of Political Economy, Vol. 110, no 6, pp. 1175-1219. 
Grund, C. (2000), Wages and Risk Compensation in Germany, IZA Discussion Paper No. 221.

Hagler-Bailly Consulting, Inc. (1995), Human Health Benefits Assessment of the Acid Rain Provisions on the 1990 Clean Air Act Amendments, final report for USEPA, Acid Rain Division. Helwege, J. (1992), Sectoral Shifts and Inter-Industry Wage Differentials, Journal of Labor Economics, Vol. 10, pp. 55-84.

Henderson, V. (1996). Effects of Air Quality Regulation. American Economic Review, 86, pp. 789-813.

Hwang, H.S., Reed, W.R. and Hubbard, C. (1990), Compensating Wage Differentials and Unobserved Productivity, Journal of Political Economy, Vol. 100, pp. 835-858.

Kahn, M.E. (1997). Particulate Pollution Trends in the United States. Journal of Regional Science and Urban Economics, 27, pp. 87-107.

Kostiuk, P.F. (1990), Compensating Differentials for Shift Work, Journal of Political Economy, Vol. 98, 5, pp. 1054-75.

Landrigan, P.J. (1992), Commentary: Environmental Disease - A Preventable Epidemic, American Journal of Public Health, Vol. 82, 7, pp. 933-941.

Leeth, J.D. and Ruser, J. (2003), Compensating Wage Differentials for Fatal and Non-Fatal Injury by Race and Gender, Journal of Risk and Uncertainty, Vol. 27, 3, pp. 257-277.

Leigh, P.J. (1995), Compensating Wages, Value of Statistical Life, and Inter-Industry Differentials, Journal of Environmental Economics and Management, Vol. 28, 1, pp. 83-97.

Lipsey, R. (1976), Comments on the Value of Saving a Life: Evidence from the Labor Market, In N. Terleckyj, ed., Household Production and Consumption, New York: NBER/Columbia University Press. Lott, J.R. and Manning, R.L. (2000), Have Changing Liability Rules Compensated Workers Twice for Occupational Hazards? Earnings Premiums and Cancer Risks, Journal of Legal Studies Vol. 29, pp. 99-130. 
Morgenstern, R.D., Pizer, W.A. and Shih, J.S. (2002), Jobs Versus the Environment: An IndustryLevel Perspective. Journal of Environmental Economics and Management, Vol. 43, pp. 412-36.

Moulton, B (1990), An illustration of a pitfall in estimating the effects of aggregate variables on micro units, The Review of Economics and Statistics, Vol. 72, 2, pp. 334-338.

Mrozek, J. R., and Taylor, L. O. (1999), What Determines the Value-of-Life: A Meta-Analysis, Department of Economics: Georgia State University.

Murphy, K.M. and Topel, R.H. (1987), Unemployment, Risk and Earnings: Testing for Equalizing Wage Differences in the Labor Market, in "Unemployment and the Structure of Labor Markets," (K. Lang and J. Leonard, Eds.), Basil Blackwell, London.

Pope, C.A. and others, (1995), Particulate Air Pollution as A Predictor of Mortality in a Prospective Study of U.S. Adults, American Journal of Critical Care Medicine, Vol. 151, 3, pp. 669-74.

Robinson, J.C. (1991), Toil and Toxics: Workplace Struggles and Political Strategies for Occupational Safety and Health, Berkley: University of California Press.

Shilling, S. and Brackbill, R.M. (1987), Occupational Health and Safety Rules and Potential Health Consequences for U.S. Workers, 1985, Public Health Reports, Vol. 102: pp. 36-46.

Shogren, J.F. and Stamland, T. (2002), Skill and the Value of Life, Journal of Political Economy, Vol. 110, 5, pp. 1168-1173.

Sandy, R., Elliott, R.F., Siebert, W.S. and Wei, X. (2001), Measurement Error and the Effects of Unions on the Compensating Differentials for Fatal Workplace Risks, Journal of Risk and Uncertainty, Vol. 23, 1, pp. 33-56.

Siebert, W.S. and Wei, X. (1994), Compensating Wage Differentials for Workplace Accidents: Evidence for Union and Nonunion Workers in the UK, Journal of Risk and Uncertainty, Vol. 9, 1, pp. 61-76. 
Stevens, G (1992), Workplace injury: a view from HSE's trailer to the 1990 Labour Force Survey, Employment Gazette, December, Vol. 100, 12, pp. 621-638.

U.S. Environmental Protection Agency, (1997), The Benefits and Costs of the Clean Air Act 19701990, Prepared for the U.S. Congress by the US EPA. (October).

Vineis, P. and Simonato, L. (1991). The Proportion of Lung and Bladder Cancer in Males Resulting from Occupation: A Systematic Approach. Archives of Environmental Health, 46, 6.

Viscusi, W.K. and O’Connor, C. (1984). Adaptive Responses to Chemical Labeling: Are Workers Bayesian Decision Makers? American Economic Review, Vol. 74, No. 5, pp. 942-956.

Viscusi, W.K. (1993), The Value of Risks to Life and Health, Journal of Economic Literature, Vol. 31, pp. 1912-1946.

Viscusi, W.K. (2004). The Value of Life: Estimates with Risks by Occupation and Industry, Economic Inquiry, Vol. 42, No. 1, pp. 29-48.

Viscusi, W.K. (2003), Racial Differences in Labor Market Values of a Statistical Life, The Journal of Risk and Uncertainty, Vol. 27, 23, pp. 239-256.

Viscusi, W.K. (2007), Regulation of Health, Safety, and Environmental Risks, in A. Mitchell Polinsky and Steven Shavell, Handbook of Law and Economics, Vol. 1 (Amsterdam: Elsevier, North-Holland, 2007), pp. 592-645.

Viscusi, W.K. and Aldy, J.E. (2003), The Value of a Statistical Life: A Critical Review of Market Estimates Throughout the World, Journal of Risk and Uncertainty, Vol. 27, 1, pp. 5-76.

World Health Organization (2007), World Day for Safety and Health at Work, Press Release, http://www.ilo.org/public/english/protection/safework/worldday/index.htm.

Wiggins S.N. and Ringleb, A.H. (1992), Adverse selection and long-term hazards: The choice between contract and mandatory liability rules, Journal of Legal Studies, Vol. 21, 1, pp. 189-215. 


\section{Appendix}

[Table 4 about here]

[Table 5 about here]

[Table 6 about here]

[Table 7 about here] 
Table 1: OLS estimates of the impact of pollution and risk on (log) wages of manual workers (estimated coefficients).

\begin{tabular}{|c|c|c|c|c|c|c|c|}
\hline & & \multicolumn{2}{|c|}{$\begin{array}{c}\text { Pollution per unit } \\
\text { of value added }\end{array}$} & \multicolumn{2}{|c|}{$\begin{array}{l}\text { Pollution } \\
\text { per firm }\end{array}$} & \multicolumn{2}{|c|}{ Pollution } \\
\hline & & Base & Full & Base & Full & Base & Full \\
\hline \multirow[t]{4}{*}{$\begin{array}{l}\text { All } \\
\text { Pollutants }\end{array}$} & Pollution & $\begin{array}{l}2.26^{*} \\
(1.207)\end{array}$ & $\begin{array}{l}1.87 * * \\
(1.124)\end{array}$ & $\begin{array}{l}89.823 * * * \\
(32.76)\end{array}$ & $\begin{array}{l}59.53 \\
(37.08)\end{array}$ & $\begin{array}{l}0.267 \\
(0.169)\end{array}$ & $\begin{array}{l}0.114 \\
(0.184)\end{array}$ \\
\hline & Fatal Risk & - & $\begin{array}{l}0.012^{* *} \\
(0.0064)\end{array}$ & - & $\begin{array}{l}0.0133^{* *} \\
(0.006)\end{array}$ & - & $\begin{array}{l}0.014 * * \\
(0.0067)\end{array}$ \\
\hline & $\begin{array}{l}\text { Non-Fatal } \\
\text { Risk }\end{array}$ & - & $\begin{array}{l}-0.00013 \\
(0.00012)\end{array}$ & - & $\begin{array}{l}-0.00012 \\
(0.00012)\end{array}$ & - & $\begin{array}{l}-0.00013 \\
(0.00012)\end{array}$ \\
\hline & R-squared & 0.4318 & 0.4323 & 0.4315 & 0.4320 & 0.4314 & 0.4320 \\
\hline \multirow[t]{4}{*}{$\begin{array}{l}\text { Heavy } \\
\text { Metals }\end{array}$} & Pollution & $\begin{array}{l}27.17 \\
(16.36)\end{array}$ & $\begin{array}{l}26.521 \\
(16.56)\end{array}$ & $\begin{array}{l}\text { 6910.71*** } \\
\text { (1363.44) }\end{array}$ & $\begin{array}{l}6,658.1^{* * *} \\
(1,616.6)\end{array}$ & $\begin{array}{l}8.804 \\
(6.072)\end{array}$ & $\begin{array}{l}7.494 \\
(6.901)\end{array}$ \\
\hline & Fatal Risk & - & $\begin{array}{l}0.0139 * * \\
(0.0059)\end{array}$ & - & $\begin{array}{l}0.0135^{* *} \\
(0.0057)\end{array}$ & - & $\begin{array}{l}0.0129 * * \\
(0.0064)\end{array}$ \\
\hline & $\begin{array}{l}\text { Non-Fatal } \\
\text { Risk }\end{array}$ & - & $\begin{array}{l}-0.00014 \\
(0.00012)\end{array}$ & - & $\begin{array}{l}-0.00012 \\
(0.00012)\end{array}$ & - & $\begin{array}{l}-0.00014 \\
(0.00012)\end{array}$ \\
\hline & R-squared & 0.4320 & 0.4327 & 0.4327 & 0.4333 & 0.4317 & 0.4322 \\
\hline \multirow[t]{4}{*}{ Local Air } & Pollution & $\begin{array}{l}2.407^{*} \\
(1.259)\end{array}$ & $\begin{array}{l}1.946^{*} \\
(1.117)\end{array}$ & $\begin{array}{l}89.11 * * * \\
(29.28)\end{array}$ & $\begin{array}{l}56.32 * \\
(33.427)\end{array}$ & $\begin{array}{l}0.258 \\
(0.175)\end{array}$ & $\begin{array}{l}0.0884 \\
(0.185)\end{array}$ \\
\hline & Fatal Risk & - & $\begin{array}{l}0.0126^{*} \\
(0.0064)\end{array}$ & - & $\begin{array}{l}0.0135^{* *} \\
(0.0065)\end{array}$ & - & $\begin{array}{l}0.0142^{* *} \\
(0.0067)\end{array}$ \\
\hline & $\begin{array}{l}\text { Non-Fatal } \\
\text { Risk }\end{array}$ & - & $\begin{array}{l}-0.00013 \\
(0.00012)\end{array}$ & - & $\begin{array}{l}-0.00012 \\
(0.00012)\end{array}$ & - & $\begin{array}{l}-0.00013 \\
(0.00012)\end{array}$ \\
\hline & R-squared & 0.4317 & 0.4322 & 0.4314 & 0.4320 & 0.4313 & 0.4319 \\
\hline \multirow[t]{5}{*}{$\begin{array}{l}\text { Other } \\
\text { Pollution }\end{array}$} & Pollution & $\begin{array}{l}2.395^{*} \\
(1.217)\end{array}$ & $\begin{array}{l}1.937^{*} \\
(1.109)\end{array}$ & $\begin{array}{l}86.209 * * \\
(28.52)\end{array}$ & $\begin{array}{l}54.81 * \\
(32.74)\end{array}$ & $\begin{array}{l}0.258 \\
(0.165)\end{array}$ & $\begin{array}{l}0.0959 \\
(0.177)\end{array}$ \\
\hline & Fatal Risk & - & $\begin{array}{l}0.0123 * \\
(0.0064)\end{array}$ & - & $\begin{array}{l}0.0134 * * \\
(0.0065)\end{array}$ & - & $\begin{array}{l}0.0141^{* *} \\
(0.0068)\end{array}$ \\
\hline & $\begin{array}{l}\text { Non-Fatal } \\
\text { Risk }\end{array}$ & - & $\begin{array}{l}-0.00013 \\
(0.00012)\end{array}$ & - & $\begin{array}{l}-0.00012 \\
(0.00012)\end{array}$ & - & $\begin{array}{l}-0.00013 \\
(0.00012)\end{array}$ \\
\hline & R-squared & 0.4318 & 0.4323 & 0.4315 & 0.4320 & 0.4313 & 0.4319 \\
\hline & Observations & \multicolumn{2}{|c|}{52894} & \multicolumn{2}{|c|}{52894} & \multicolumn{2}{|c|}{52894} \\
\hline
\end{tabular}

The base model contains a full set of controls but excludes fatal and non-fatal risk.

Clustered standard errors in parentheses, $* * *, * *$ and $*$ denote significance at $99 \%, 95 \%$ and $90 \%$, respectively.

The risk coefficients are based on a denominator of 100,000 workers. 
Table 2: OLS estimates of the impact of pollution on (log) wages in the top five dirty industries

(all pollutants only, estimated coefficients and standard errors)

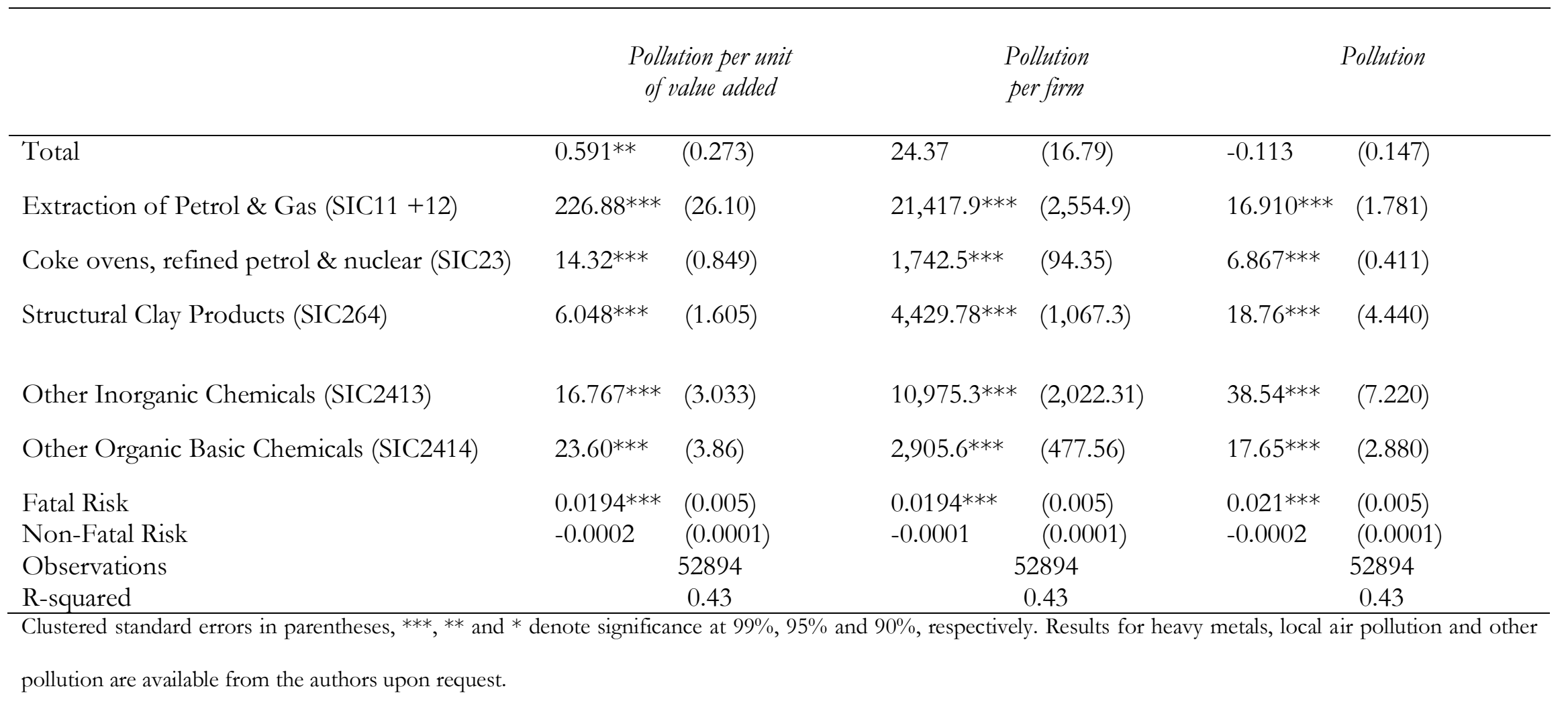


Table 3: Wage premia in dirty industries (Pounds $\mathcal{E}$ per week and as a percentage of the average weekly wage in each industry)

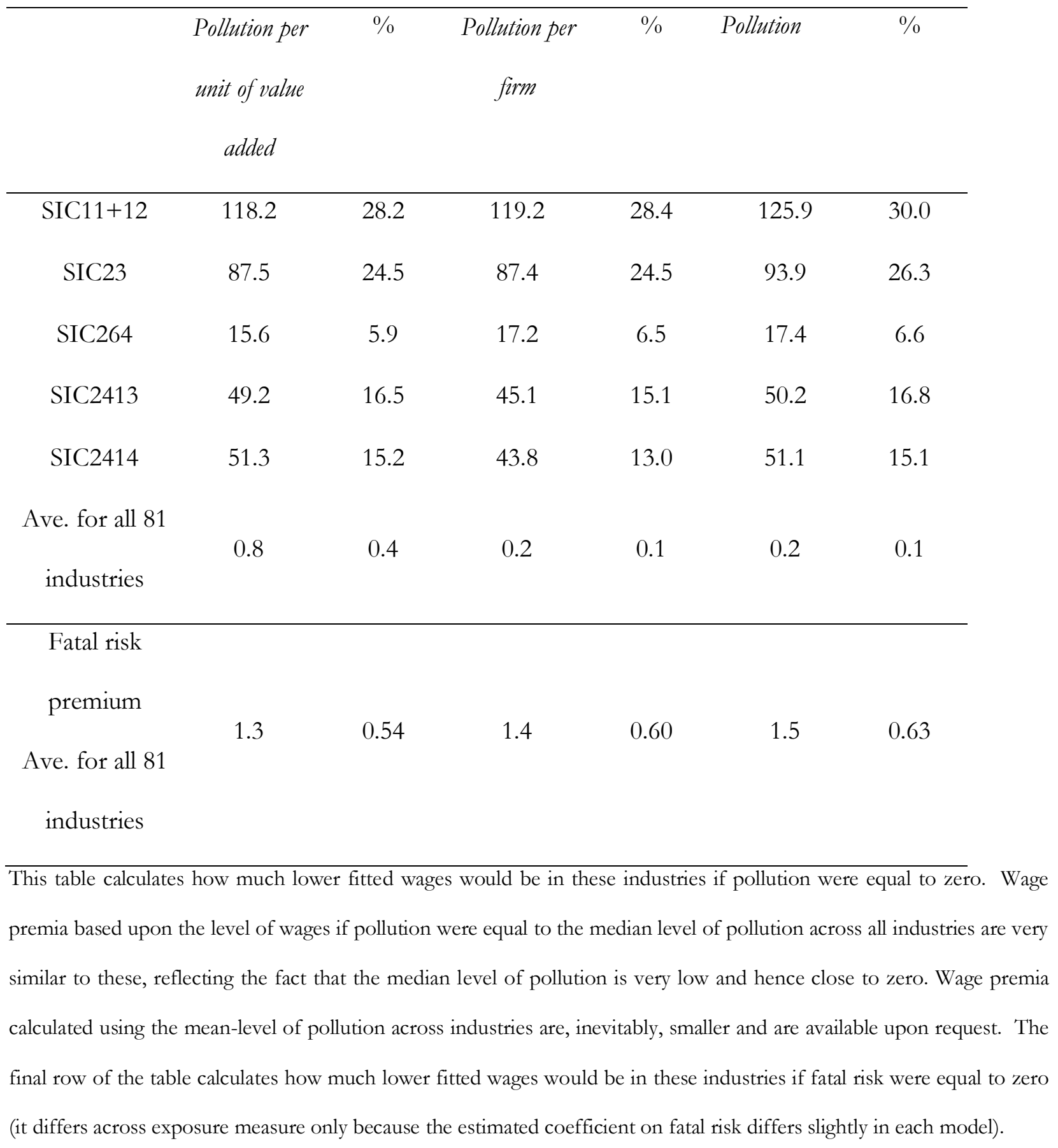


Table 4: UK Environment Agency Industry Classification and SIC92 concordance

\begin{tabular}{|c|c|c|c|}
\hline SIC92 & Description & SIC92 & Description \\
\hline 1 & Agriculture & 32 & Radio, television and comms. \\
\hline 2 & Forestry & 33 & Medical, precision, optical inst. \\
\hline 5 & Fishing & 34 & Motor vehicles and trailers \\
\hline 10 & Mining of coal & 35 & Other transport equipment \\
\hline $11+12$ & Extraction of petrol and gas & $36+37$ & Manufacture of other products \\
\hline 13 & Mining of metal ores & 40.1 & Electricity production \\
\hline 14 & Other mining & $40.2+40.3$ & Gas distribution \\
\hline 15 & Food and beverages & 41 & Water supply \\
\hline 16 & Tobacco products & 45 & Construction \\
\hline 17 & Textiles & 50 & Garages, car showrooms \\
\hline 18 & Clothing manufacture & 51 & $\begin{array}{l}\text { Wholesale trade not motor } \\
\text { vehicles }\end{array}$ \\
\hline 19 & Leather, luggage \& footwear & 52 & Retail \& repair except motor \\
\hline 20 & Timber & 55 & Hotels and restaurants \\
\hline 21 & Pulp and paper & 60.1 & Railways \\
\hline 22 & Publishing and printing & $60.2+60.3$ & Buses and coaches \\
\hline 23 & $\begin{array}{l}\text { Coke oven, refined petrol \& } \\
\text { nuclear }\end{array}$ & $60.2+60.3$ & Tubes and trams \\
\hline $24.11+24.12$ & Industrial gases, dyes, pigments & $60.2+60.3$ & Taxis operation \\
\hline 24.13 & Other inorganic chemicals & $60.2+60.3$ & Freight transport by road \\
\hline 24.14 & Other organic basic chemicals & $60.2+60.3$ & Transport via pipeline \\
\hline 24.15 & Fertilisers, nitrogen compounds & 61 & Water transport \\
\hline $24.16+24.17$ & Plastics and synthetic rubber & 62 & Air transport \\
\hline 24.2 & Pesticides, agro-chemicals & 63 & Supporting transport activities \\
\hline 24.3 & Paints, varnishes, ink etc & $64.1+64.2$ & Post and telecommunications \\
\hline 24.4 & Pharmaceuticals & 65 & Financial intermediation \\
\hline 24.5 & Soap and detergents & 66 & Insurance and pensions \\
\hline 24.6 & Chemical products n.e.s & 67 & Auxiliary finance activities \\
\hline 24.7 & Man-made fibres & $70.1+70.2+70.3$ & Real estate activities \\
\hline 25.1 & Rubber products & 71 & Renting of machinery \\
\hline 25.2 & Plastic products & 72 & Computer and related activities \\
\hline 26.1 & Glass and glass products & 73 & Research and development \\
\hline $26.2+26.3$ & Ceramic goods & 74 & Other business activities \\
\hline 26.4 & Structural clay products & 75 & public admininstration \\
\hline 26.5 & Cement, lime and plaster & 80 & Education \\
\hline $26.6+26.7+26.8$ & Concrete, stone etc & 85 & $\begin{array}{l}\text { Health and vet services, social } \\
\text { work }\end{array}$ \\
\hline $27.1+27.2+27.3$ & Iron and steel & 90 & sewage and waste \\
\hline 27.4 & Non-ferrous metals & 91 & Activities of membership orgs. \\
\hline 27.5 & Casting of metals & 92 & Recreation and sporting activities \\
\hline 28 & Fabricated metal products & 93 & Other service activities \\
\hline 29 & Machinery \& equipment & 95 & Private households \\
\hline 30 & Office machinery, computers & & \\
\hline 31 & $\begin{array}{l}\text { Electrical machinery \& } \\
\text { apparatus }\end{array}$ & & \\
\hline
\end{tabular}


Table 5: Pollutants Groupings

\begin{tabular}{|c|c|c|c|}
\hline $\begin{array}{c}\text { All } \\
\text { Pollutants }\end{array}$ & $\begin{array}{l}\text { Heavy } \\
\text { Metals }\end{array}$ & $\begin{array}{l}\text { Local } \\
\text { Air }\end{array}$ & $\begin{array}{l}\text { Other Pollutants } \\
\text { (all non-heavy metals) }\end{array}$ \\
\hline Sulphur Dioxide & & Sulphur Dioxide & Sulphur Dioxide \\
\hline Nitrogen Oxides & & Nitrogen Oxides & Nitrogen Oxides \\
\hline Ammonia & & Ammonia & Ammonia \\
\hline Carbon Monoxide & & Carbon Monoxide & Carbon Monoxide \\
\hline $\begin{array}{l}\text { Particulate Matter } \\
\text { (pm10) }\end{array}$ & & $\begin{array}{l}\text { Particulate Matter } \\
\qquad(\mathrm{pm} 10)\end{array}$ & $\begin{array}{c}\text { Particulate Matter } \\
(\text { pm10) }\end{array}$ \\
\hline Non-methane Volatile & & Non-methane Volatile & Non-methane Volatile \\
\hline Organic Compounds & & Organic Compounds & Organic Compounds \\
\hline Benzene & & & Benzene \\
\hline Butadiene & & & Butadiene \\
\hline Lead & Lead & & \\
\hline Cadmium & Cadmium & & \\
\hline Arsenic & Arsenic & & \\
\hline Mercury & Mercury & & \\
\hline Copper & Copper & & \\
\hline Chromium & Chromium & & \\
\hline Nickel & Nickel & & \\
\hline Selenium & Selenium & & \\
\hline Vanadium & Vanadium & & \\
\hline Zinc & Zinc & & \\
\hline Carbon Dioxide & & & Carbon Dioxide \\
\hline Methane & & & Methane \\
\hline Nitrous Oxides & & & Nitrous Oxides \\
\hline
\end{tabular}


Table 6. Table of Sample Means.

\begin{tabular}{|c|c|c|c|c|c|}
\hline & Mean & S.D. & & Mean & S.D. \\
\hline Gross Weekly Pay & 240.85 & 114.71 & Female $^{\mathrm{A}}$ & 0.21 & 0.41 \\
\hline Total Emissions (Pollution) see eq'n (2) & 0.01 & 0.03 & Foreign Born ${ }^{A}$ & 0.05 & 0.22 \\
\hline $\begin{array}{l}\text { Emissions/GVA (Pollution per unit of value } \\
\text { added) see eq'n (3) }\end{array}$ & 0.001 & 0.005 & White ${ }^{A}$ & 0.96 & 0.18 \\
\hline $\begin{array}{l}\text { Emissions / No Firms (Pollution per firm) see } \\
\text { eq'n (4) }\end{array}$ & 0.00001 & 0.0001 & Black Caribbean $^{\mathrm{A}}$ & 0.01 & 0.09 \\
\hline $\begin{array}{l}\text { Fatal Risk (industry level fatalities per } \\
100,000 \text { workers) }\end{array}$ & 1.57 & 1.91 & Black African ${ }^{A}$ & 0.003 & 0.05 \\
\hline $\begin{array}{l}\text { Non-Fatal Risk (industry level non-fatal } \\
\text { injuries per 100,000 workers) }\end{array}$ & 184.35 & 119.16 & Black Other ${ }^{A}$ & 0.001 & 0.03 \\
\hline Poor Health ${ }^{\mathrm{A}}$ & 0.08 & 0.27 & Indian ${ }^{A}$ & 0.01 & 0.11 \\
\hline Union Member ${ }^{\mathrm{A}}$ & 0.37 & 0.48 & PakistaniA & 0.004 & 0.06 \\
\hline Worked for Firm $>5 \mathrm{yrs}^{\mathrm{A}}$ & 0.47 & 0.50 & 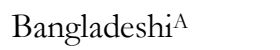 & 0.001 & 0.03 \\
\hline Shift Work ${ }^{\mathrm{A}}$ & 0.30 & 0.46 & Chinese $^{A}$ & 0.001 & 0.03 \\
\hline Evening Work ${ }^{\mathrm{A}}$ & 0.17 & 0.38 & Other Non-White ${ }^{A}$ & 0.01 & 0.08 \\
\hline Night Work ${ }^{\mathrm{A}}$ & 0.20 & 0.40 & Married $^{\mathrm{A}}$ & 0.62 & 0.49 \\
\hline Growth GVA & -0.75 & 10.69 & Observed in $1996^{\mathrm{A}}$ & 0.17 & 0.37 \\
\hline PCI & 0.75 & 0.08 & Observed in $1997^{\mathrm{A}}$ & 0.16 & 0.37 \\
\hline Firm Size & 0.56 & 0.28 & Observed in $1998^{\mathrm{A}}$ & 0.16 & 0.37 \\
\hline Agriculture ${ }^{A}$ & 0.0003 & 0.02 & Observed in 1999A & 0.16 & 0.36 \\
\hline Fishing ${ }^{A}$ & 0.0001 & 0.01 & Observed in $2000^{A}$ & 0.14 & 0.35 \\
\hline Mining $^{A}$ & 0.01 & 0.09 & Observed in $2001^{\mathrm{A}}$ & 0.11 & 0.31 \\
\hline Manufacturing ${ }^{A}$ & 0.41 & 0.49 & Observed in $2002^{\mathrm{A}}$ & 0.10 & 0.30 \\
\hline Utilities $^{\mathrm{A}}$ & 0.01 & 0.10 & North $^{\mathrm{A}}$ & 0.07 & 0.25 \\
\hline Construction $^{\mathrm{A}}$ & 0.11 & 0.31 & Yorkshire $^{\mathrm{A}}$ & 0.10 & 0.30 \\
\hline Wholesale \& Retail ${ }^{\mathrm{A}}$ & 0.11 & 0.32 & North West ${ }^{\mathrm{A}}$ & 0.10 & 0.30 \\
\hline Hotels and Restaurants ${ }^{\mathrm{A}}$ & 0.04 & 0.19 & East Midlands ${ }^{A}$ & 0.09 & 0.28 \\
\hline Transport \& Comms ${ }^{\mathrm{A}}$ & 0.13 & 0.33 & West Midlands ${ }^{\mathrm{A}}$ & 0.11 & 0.31 \\
\hline Real Estate \& Business ${ }^{\mathrm{A}}$ & 0.05 & 0.21 & East Anglia ${ }^{\mathrm{A}}$ & 0.04 & 0.20 \\
\hline Education $^{\mathrm{A}}$ & 0.03 & 0.18 & South East ${ }^{\mathrm{A}}$ & 0.23 & 0.42 \\
\hline Health \& Social Work ${ }^{\mathrm{A}}$ & 0.06 & 0.24 & South West ${ }^{\mathrm{A}}$ & 0.08 & 0.27 \\
\hline Other Sector ${ }^{\mathrm{A}}$ & 0.04 & 0.21 & Wales $^{\mathrm{A}}$ & 0.05 & 0.22 \\
\hline Age & 39 & 12.14 & Scotland ${ }^{A}$ & 0.10 & 0.30 \\
\hline Degree as Highest Qual ${ }^{\mathrm{A}}$ & 0.05 & 0.23 & Northern Ireland ${ }^{A}$ & 0.03 & 0.17 \\
\hline $\mathrm{Al}$ evel as Highest Qual ${ }^{\mathrm{A}}$ & 0.39 & 0.49 & Regional U Rate & 0.09 & 0.02 \\
\hline O level as Highest Qual ${ }^{\mathrm{A}}$ & 0.15 & 0.36 & Manager $^{A}$ & 0.00002 & 0.004 \\
\hline Other as Highest Qual ${ }^{\mathrm{A}}$ & 0.21 & 0.40 & $\mathrm{~N}$ & 52894 & \\
\hline No Qualifications ${ }^{A}$ & 0.80 & 0.38 & & & \\
\hline
\end{tabular}

\footnotetext{
A denotes a $0 / 1$ dichotomous dummy variable. SD refers to the standard deviation. Equivalent full specification results
} for heavy metals, local air, and other pollution are available on request. 
Table 7: OLS (log) Wage equation for all pollutants, full specification (1995-2003)

\begin{tabular}{|c|c|c|c|c|c|c|c|c|}
\hline \multirow[b]{2}{*}{ Variable } & \multicolumn{2}{|c|}{$\begin{array}{c}\text { Pollution per unit of } \\
\text { value added }\end{array}$} & \multicolumn{3}{|c|}{$\begin{array}{l}\text { Pollution } \\
\text { per firm }\end{array}$} & \multicolumn{3}{|c|}{ Pollution } \\
\hline & Coefficient & $\mathrm{SE}$ & Coefficient & $\mathrm{SE}$ & & Coefficient & $\mathrm{SE}$ & \\
\hline Emissions & 1.875 & 1.124 & 59.536 & 37.089 & & 0.114 & 0.185 & \\
\hline Fatal Risk & 0.012 & 0.006 & 0.013 & 0.007 & & 0.014 & 0.007 & \\
\hline Non-Fatal Risk & -0.0001 & 0.0001 & -0.0001 & 0.0001 & & -0.0001 & 0.0001 & \\
\hline Health & -0.085 & 0.006 & -0.085 & 0.006 & & -0.085 & 0.006 & \\
\hline Union & 0.101 & 0.009 & 0.101 & 0.009 & & 0.101 & 0.009 & \\
\hline Tenure & 0.086 & 0.014 & 0.086 & 0.014 & & 0.087 & 0.014 & \\
\hline Shift work & 0.078 & 0.011 & 0.078 & 0.011 & & 0.078 & 0.011 & \\
\hline Evening work & 0.026 & 0.005 & 0.026 & 0.005 & & 0.026 & 0.005 & \\
\hline Night work & 0.099 & 0.005 & 0.099 & 0.005 & & 0.099 & 0.005 & \\
\hline Industry growth & 0.001 & 0.0004 & 0.001 & 0.0004 & & 0.001 & 0.0004 & \\
\hline PCI & 0.144 & 0.100 & 0.136 & 0.100 & & 0.138 & 0.100 & \\
\hline Firm Size & 0.141 & 0.043 & 0.139 & 0.042 & & 0.144 & 0.043 & \\
\hline Age & 0.057 & 0.007 & 0.057 & 0.007 & & 0.057 & 0.007 & \\
\hline Age squared & -0.001 & 0.0001 & -0.001 & 0.0001 & & -0.001 & 0.0001 & \\
\hline Degree & 0.293 & 0.015 & 0.294 & 0.015 & & 0.294 & 0.015 & \\
\hline A level & 0.168 & 0.007 & 0.168 & 0.007 & & 0.168 & 0.007 & \\
\hline O level & 0.074 & 0.011 & 0.074 & 0.011 & & 0.074 & 0.011 & \\
\hline Other Qualification & 0.046 & 0.007 & 0.046 & 0.007 & & 0.046 & 0.007 & \\
\hline Female & -0.284 & 0.011 & -0.284 & 0.011 & & -0.284 & 0.011 & \\
\hline Foreign Born & 0.026 & 0.010 & 0.026 & 0.010 & & 0.026 & 0.010 & \\
\hline Black Caribbean & -0.044 & 0.018 & -0.044 & 0.018 & & -0.044 & 0.018 & \\
\hline Black African & -0.102 & 0.044 & -0.102 & 0.044 & & -0.102 & 0.044 & \\
\hline Black Other & 0.072 & 0.054 & 0.071 & 0.054 & & 0.071 & 0.054 & \\
\hline Indian & -0.150 & 0.020 & -0.150 & 0.020 & & -0.150 & 0.020 & \\
\hline Pakistani & -0.210 & 0.030 & -0.210 & 0.030 & & -0.210 & 0.030 & \\
\hline Bangladeshi & -0.532 & 0.098 & -0.532 & 0.098 & & -0.532 & 0.098 & \\
\hline Chinese & -0.127 & 0.059 & -0.127 & 0.059 & & -0.127 & 0.059 & \\
\hline Other ethnic & -0.047 & 0.021 & -0.047 & 0.021 & & -0.047 & 0.021 & \\
\hline Married & 0.054 & 0.006 & 0.054 & 0.006 & & 0.054 & 0.006 & \\
\hline Unemployment Rate & 0.512 & 0.384 & 0.511 & 0.385 & & 0.513 & 0.385 & \\
\hline Manager dummy & 0.760 & 0.022 & 0.758 & 0.022 & & 0.756 & 0.022 & \\
\hline Constant & -0.069 & 0.143 & -0.069 & 0.143 & & -0.073 & 0.143 & \\
\hline Region dummies & YES & YES & YES & & YES & YES & & YES \\
\hline Sector dummies & YES & YES & YES & & YES & YES & & YES \\
\hline Year dummies & $\begin{array}{r}\text { YES } \\
0.43\end{array}$ & YES & YES & 432 & YES & $\begin{array}{r}\text { YES } \\
0.4\end{array}$ & & YES \\
\hline $\mathrm{N}$ & 5289 & & & 894 & & 528 & & \\
\hline
\end{tabular}

The default individual in our regressions is native born; white; male; that has no qualifications; lives in the South West; works in the agricultural industry, does not work any type of unsociable hours and is a non-manager. 